\title{
Renal Dysfunction in Cirrhosis: Critical Care Management
}

\author{
Akila Rajakumar ${ }^{1} \oplus$, Ellango Appuswamy ${ }^{2}$, Ilankumaran Kaliamoorthy ${ }^{3}$, Mohamed Rela ${ }^{4}$
}

\begin{abstract}
Cirrhotic patients with manifestations of the end-stage liver disease have a high risk for developing renal dysfunction even with minor insults. The development of renal dysfunction increases the morbidity and mortality of these patients. Causes of renal dysfunction in cirrhotics can be due to hepatorenal syndrome (HRS) or acute kidney injury (AKI) resulting from prerenal, renal, and postrenal causes. Development of pretransplant renal dysfunction has been shown to affect post-liver transplantation outcomes. Early detection and aggressive strategies for the prevention of further progression of renal dysfunction seem to decrease the morbidity and improve survival in this group of patients. This article aims to outline the pathogenesis of renal dysfunction in cirrhosis, etiological factors, and evaluation of renal dysfunction, strategies for aggressive therapy for renal dysfunction, the indications of renal replacement therapy (RRT) in this group of patients, and the various modalities of RRT with their merits and demerits. A thorough understanding of the pathogenesis, early detection, and aggressive corrective measures for AKI can prevent further progression. In conclusion, a good knowledge of treatment modalities available for renal dysfunction in cirrhosis and institution of timely interventions can significantly improve survival in this group of patients.

Keywords: Acute kidney injury in cirrhosis, Dialysis in cirrhosis, Hepatorenal syndrome, Renal dysfunction in cirrhosis, Renal replacement therapy in cirrhosis, Volume overload in cirrhosis.

Key messages: Development of renal dysfunction in cirrhotics increases the morbidity and mortality of these patients and results in poor outcomes after liver transplantation. Early detection and aggressive strategies for the prevention of further progression of renal dysfunction seem to decrease the morbidity and improve survival in this group of patients.

Indian Journal of Critical Care Medicine (2021): 10.5005/jp-journals-10071-23721
\end{abstract}

\section{INTRODUCTION}

Renal dysfunction significantly increases the morbidity and mortality of cirrhotic patients with the end-stage liver disease (ESLD) awaiting liver transplantation. ${ }^{1}$ Renal dysfunction in the preoperative period has shown to adversely affect outcomes after liver transplantation. ${ }^{2-4}$ Introduction of Model for End-stage Liver Disease (MELD) score for organ allocation in 2002 has decreased the waiting time of these patients prior to liver transplantation resulting in improved outcomes although some studies have shown varied results. ${ }^{5-7}$ Development of renal dysfunction in cirrhotics has huge clinical and financial implications in terms of prolonged requirement for intensive care and organ support, including mechanical ventilation and renal replacement therapy (RRT). Early identification of renal dysfunction can help to prevent further deterioration and requirement of RRT. However, this may be a challenge as an ideal test for defining renal impairment in cirrhotic patients is still not clearly defined.

In this review, we discuss the pathogenesis and enhanced susceptibility for renal dysfunction in cirrhosis, etiology of renal dysfunction in this subset of patients, and evaluation and management of renal dysfunction in the critical care setting.

\section{Increased Susceptibility to Renal Dysfunction: Altered Cardiovascular Dynamics in Cirrhosis}

Patients with ESLD are susceptible to renal dysfunction due to disturbances in the circulatory system. In portal hypertension, extensive splanchnic vasodilation occurs because of excessive release and impaired clearance of vasodilatory mediators like nitric oxide, carbon monoxide, and cannabinoids resulting

\begin{abstract}
${ }^{1,3}$ Department of Liver Anaesthesia and Intensive Care, Dr. Rela Institute and Medical Centre, Chennai, Tamil Nadu, India

${ }^{2}$ Department of Liver Anaesthesia and Intensive Care, Gleneagles Global Health City, Chennai, Tamil Nadu, India

${ }^{4}$ Department of Liver Transplantation and HPB Surgery, Dr. Rela Institute and Medical Centre, Chennai, Tamil Nadu, India

Corresponding Author: Akila Rajakumar, Department of Liver Anaesthesia and Intensive Care, Dr. Rela Institute and Medical Centre, Chennai, Tamil Nadu, India, Phone: +91 9840136295, e-mail: drakila. rajakumar@gmail.com

How to cite this article: Rajakumar A, Appuswamy E, Kaliamoorthy I, Rela M. Renal Dysfunction in Cirrhosis: Critical Care Management. Indian J Crit Care Med 2021;25(2):207-214.

Source of support: Nil

Conflict of interest: None
\end{abstract}

in decreased systemic vascular resistance. ${ }^{8}$ This circulatory dysfunction is compensated in the early stages of cirrhosis by the increased cardiac output, thus preserving renal perfusion. But as the disease advances, the increased cardiac output is no longer capable of maintaining other organ perfusion, thus activating endogenous vasoconstrictor systems, namely, renin-angiotensin aldosterone system and the sympathetic nervous system. This has important consequences on renal function by causing intrarenal vasoconstriction and hypoperfusion. Other important effects on renal function include solute-free water retention resulting in ascites and edema. ${ }^{9-13}$ Therefore, these patients are very prone to develop renal dysfunction with even minor insults. 


\section{Causes of Renal Dysfunction in Cirrhosis}

Renal dysfunction in cirrhotics can be broadly classified into two main groups: (a) hepatorenal syndrome (HRS) and (b) acute kidney injury (AKI) due to various factors.

\section{HRS Classification and Diagnostic Criteria for HRS}

HRS is a diagnosis of exclusion after all prerenal, renal, and postrenal causes of AKI are ruled out. The incidence of HRS in decompensated cirrhotics is around $18 \%$ in the first year, which can increase up to $39 \%$ over a 5 -year period. ${ }^{14}$

HRS is classified into 2 types. Type 1 HRS is characterized by a rapid and abrupt elevation in serum creatinine, to a value more than $50 \%$ from the baseline, reaching a level higher than $2.5 \mathrm{mg} / \mathrm{dL}$ in less than two weeks' duration, and is associated with a rapid progression and a median survival of less than a month, if left untreated. In Type $2 \mathrm{HRS}$, there is a gradual elevation of serum creatinine levels in the range of $1.2-2.5 \mathrm{mg} / \mathrm{dL}$ and more frequently associated with diuretic resistant and/or refractory ascites with relatively stable liver function. Type 2 HRS patients may eventually develop Type 1 HRS gradually, or it may be precipitated by a trigger event such as spontaneous bacterial peritonitis (SBP). Type $1 \mathrm{HRS}$ has poorer prognosis in comparison with the Type $2 .{ }^{9}$

Munoz described 2 additional types of HRS. In Type 3 HRS, decompensated cirrhotic patients with long-standing diabetic nephropathy, obstructive renal disease, or chronic glomerulonephritis can develop HRS from a precipitating event or worsening liver failure. ${ }^{15}$ Conditions such as immune-mediated glomerulonephritis or other intrinsic renal disease are evident on renal biopsy in at least $42 \%$ of cirrhotics. ${ }^{16}$ Type 4 HRS is described in acute liver failure.

Major diagnostic criteria for HRS as proposed by the International Ascites Club include (a) serum creatinine level $>1.5 \mathrm{mg} / \mathrm{dL}$; (b) no improvement in serum creatinine level (decrease to $1.5 \mathrm{mg} / \mathrm{dL}$ or less) after at least 2 days of diuretic withdrawal and volume expansion with albumin given at a dose of $1 \mathrm{~g} / \mathrm{kg}$ per day up to a maximum of $100 \mathrm{~g}$; absence of parenchymal kidney disease as indicated by proteinuria $>500 \mathrm{mg} / \mathrm{d}$ and/or microhematuria $>50$ red blood cells per high power field; exclusion of urinary tract outflow disturbances (normal renal ultrasonography); no current or recent treatment with nephrotoxic drugs or vasodilators; and absence of septic or hemorrhagic shock. ${ }^{17}$ Less important and not regularly occurring diagnostic features of HRS (minor criteria) are urine volume $<400 \mathrm{~mL} / \mathrm{d}$, low sodium concentration in the serum $(<130 \mathrm{mEq} / \mathrm{L})$ and urine $(<10 \mathrm{mEq} / \mathrm{L})$, and urine osmolarity greater than serum osmolarity. ${ }^{9,18}$ These criteria help to differentiate HRS from acute tubular necrosis (ATN).

A limiting feature in the definition proposed by the International Ascites Club is the renal response to volume expansion. Both ATN and HRS do not respond to volume expansion although some consistent gradual improvement in glomerular filtration rate (GFR) is noted in patients with Type $1 \mathrm{HRS}$. Good response to vasoconstrictors seen in HRS can be best used to differentiate it from ATN. ${ }^{3}$

\section{AKI: Definition and Classification}

AKI was defined and classified by RIFLE initially, and subsequently, AKIN criterion was introduced. Recently, KDIGO criterion for AKI was formulated and is more sensitive and better indicator for risk stratification in critically ill cirrhotics. ${ }^{19,20}$ Table 1 describes the different criteria used for defining AKI.
Table 1: Different classification systems of AKI

\begin{tabular}{|c|c|c|c|c|}
\hline Criteria & $\begin{array}{l}\text { Definition } \\
\text { of } A K I\end{array}$ & Stage & Serum creatinine & Urine output \\
\hline \multirow[t]{3}{*}{ RIFLE } & \multirow{3}{*}{$\begin{array}{l}\text { Increase in } \\
\mathrm{SCr} \geq 50 \% \\
\text { within } \\
7 \text { days }\end{array}$} & Risk & $\begin{array}{l}\geq 1.5 \text { times } \\
\text { baseline }\end{array}$ & $\begin{array}{l}\text { Less than } 0.5 \mathrm{~mL} / \\
\mathrm{kg} / \mathrm{h} \text { for more } \\
\text { than } 6 \text { hours }\end{array}$ \\
\hline & & Injury & $\geq 2$ times baseline & $\begin{array}{l}\text { Less than } 0.5 \mathrm{~mL} / \\
\mathrm{kg} / \mathrm{h} \text { for more } \\
\text { than } 12 \text { hours }\end{array}$ \\
\hline & & Failure & $\begin{array}{l}\geq 3 \text { times baseline } \\
\text { or } 0.5 \mathrm{mg} / \mathrm{dL} \\
\text { increase or } \mathrm{Cr}> \\
4.0 \mathrm{mg} / \mathrm{dL}\end{array}$ & $\begin{array}{l}\text { Less than } 0.3 \mathrm{~mL} / \\
\mathrm{kg} / \mathrm{h} \text { for } 24 \text { hours } \\
\text { or anuria for } 12 \\
\text { hours }\end{array}$ \\
\hline \multirow[t]{3}{*}{ AKIN } & \multirow{3}{*}{$\begin{array}{l}\text { Increase } \\
\text { in } \mathrm{SCr} \geq \\
0.3 \mathrm{mg} / \mathrm{dL} \\
\text { or }>50 \% \\
\text { within } 48 \\
\text { hours }\end{array}$} & 1 & $\begin{array}{l}\text { Increase of } 0.3 \\
\mathrm{mg} / \mathrm{dL} \text { or } 1.5-1.9 \\
\text { times baseline }\end{array}$ & $\begin{array}{l}\text { Less than } 0.5 \mathrm{~mL} / \\
\mathrm{kg} / \mathrm{h} \text { for more } \\
\text { than } 6 \text { hours }\end{array}$ \\
\hline & & 2 & $\begin{array}{l}\geq 2.0-2.9 \text { times } \\
\text { baseline }\end{array}$ & $\begin{array}{l}\text { Less than } 0.5 \mathrm{~mL} / \\
\mathrm{kg} / \mathrm{h} \text { for more } \\
\text { than } 12 \text { hours }\end{array}$ \\
\hline & & 3 & $\begin{array}{l}\geq 3 \text { times baseline } \\
\text { or } 0.5 \mathrm{mg} / \mathrm{dL} \\
\text { increase or } \mathrm{Cr} \\
>4.0 \mathrm{mg} / \mathrm{dL} \text { or } \\
\text { initiation of RRT }\end{array}$ & $\begin{array}{l}\text { Less than } 0.3 \mathrm{~mL} / \\
\mathrm{kg} / \mathrm{h} \text { for } 24 \text { hours } \\
\text { or anuria for } 12 \\
\text { hours }\end{array}$ \\
\hline \multirow[t]{3}{*}{ KDIGO } & \multirow{3}{*}{$\begin{array}{l}\text { Increase } \\
\text { in } \mathrm{SCr} \geq \\
0.3 \mathrm{mg} / \mathrm{dL} \\
\text { within } 48 \\
\text { hours or } \\
50 \% \text { within } \\
7 \text { days }\end{array}$} & 1 & $\begin{array}{l}\text { Increase of } 0.3 \\
\mathrm{mg} / \mathrm{dL} \text { or } 1.5-1.9 \\
\text { times baseline }\end{array}$ & $\begin{array}{l}\text { Less than } 0.5 \mathrm{~mL} / \\
\mathrm{kg} / \mathrm{h} \text { for more } \\
\text { than } 6 \text { hours }\end{array}$ \\
\hline & & 2 & $\begin{array}{l}\geq 2.0-2.9 \text { times } \\
\text { baseline }\end{array}$ & $\begin{array}{l}\text { Less than } 0.5 \mathrm{~mL} / \\
\mathrm{kg} / \mathrm{h} \text { for more } \\
\text { than } 12 \text { hours }\end{array}$ \\
\hline & & 3 & $\begin{array}{l}\geq 3 \text { times baseline } \\
\text { or } \mathrm{Cr}>4.0 \mathrm{mg} / \\
\mathrm{dL} \text { or Initiation } \\
\text { of RRT }\end{array}$ & $\begin{array}{l}\text { Less than } 0.3 \mathrm{~mL} / \\
\mathrm{kg} / \mathrm{h} \text { for } 24 \text { hours } \\
\text { or anuria for } 12 \\
\text { hours }\end{array}$ \\
\hline
\end{tabular}

Common causes of AKI in cirrhotics include hypovolemia and SBP. ${ }^{8}$ Hypovolemia can result from gastrointestinal causes like upper gastrointestinal (UGI) bleeding or diarrheal illnesses or from renal losses due to overzealous administration of diuretics. SBP is a frequently encountered etiological factor for AKI; the bacterial translocation which occurs with during the course causes extensive systemic inflammatory response, thus exaggerating the existing circulatory dysfunction. ${ }^{21-23}$ Other causes include bacterial infections, use of nephrotoxic drugs, and aggressive paracentesis without concurrent volume expansion. ${ }^{8}$

The incidence of AKI in cirrhotics varies from 26 to $50 \%$ from various studies using either RIFLE or AKIN criterion. ${ }^{24}$ Fede et al. in a review of 74 studies stated that there is a 7-fold increase in mortality in cirrhotics with renal insults. Worsening of AKI has been found to increase the risk of mortality by fourfold. ${ }^{25}$ Belcher et al. reported that in patients with worsening AKI, the mortality was found to be $83 \%$, whereas the mortality risk appears to be around $18 \%$ with no progression in $\mathrm{AKI}^{26}$

\section{Intensive Care Unit Admission with Renal Dysfunction}

The common reasons for admission of the cirrhotics with renal dysfunction to the ICU are:

- Complications of renal dysfunction-volume overload, metabolic acidosis, electrolyte disturbances, features of uremia. 
- Hemodynamic disturbances arising from the causative factor triggering the $\mathrm{AKI}^{27}$

\section{ICU Management of Cirrhotic Patients with Renal Dysfunction}

Initial assessment and evaluation of causes of renal dysfunction in these patients should be thorough to arrive at a diagnosis and initiate an appropriate treatment. ${ }^{8}$ Aggressive strategies should be initiated to prevent further progression of renal insults where possible as it has been shown to decrease mortality. ${ }^{25}$

\section{Evaluation of Renal Function}

The search for ideal biomarker which would enable us to identify renal dysfunction, differentiate its subtypes, define severity, and also predict the course of the illness would eventually lead to better management of renal dysfunction in cirrhotic patients.

\section{Serum Creatinine:pitfalls}

Because of reduced production of creatinine from the liver, malnutrition, and reduced muscle mass, serum creatinine levels in cirrhotic patients overestimate GFR sometimes as high as $50 \%$, which can delay the diagnosis of renal impairment in cirrhotics and over dosage of nephrotoxic agents in this cohort. ${ }^{28}$ Chromogenic interference with bilirubin can also lead to inaccurate creatinine values. ${ }^{29}$ Serum creatinine higher than $0.97 \mathrm{mg} / \mathrm{dL}$ in cirrhotics is equivalent to the GFR of $50 \mathrm{~mL} / \mathrm{min}$ and indicates a renal impairment. ${ }^{30}$

\section{Other Biomarkers for Renal Dysfunction}

The promising lot among the novel tubal injury biomarkers are neutrophil gelatinase-associated lipocalin (NGAL), interleukin-18 (IL 18), cystatin C, kidney injury molecule (KIM 1), and liver-type fatty acid binding protein (L-FABP). Table 2 lists the sources and the time trends of abnormalities in the biomarkers in different causes of renal injury.

Plasma and urine NGAL have been demonstrated to be sensitive, specific, and highly predictive early biomarkers of AKI after cardiac surgery in children and adult population, ${ }^{31,32}$ and these have to be studied in detail in patients with liver disease.

Cystatin $C$ levels are not influenced by muscle mass and hence can be a better predictor of GFR in cirrhotics. ${ }^{33}$ NGAL levels predicted the onset of AKI earlier than cystatin $C$ but because of commercial availability, cystatin $C$ can be a useful addendum for identifying AKI. In patients with cirrhosis, serum cystatin $C$ was found to correlate better with GFR than serum creatinine and detect early stages of renal impairment in these patients. ${ }^{34-36}$

Belcher et al. demonstrated that multiple urinary biomarkers of kidney injury can distinguish ATN from non-ATN in patients with cirrhosis and progressive AKI. ${ }^{37}$

Despite all these apparent disadvantages, serum creatinine retains an important position in identifying and prognosticating

Table 2: Novel biomarkers in kidney injury

\begin{tabular}{llll}
\hline Biomarker & Source & Sepsis & Contrast nephropathy \\
\hline NGAL & Plasma & Early & Early \\
Cystatin C & Plasma & Intermediate & Intermediate \\
NGAL & Urine & Early & Early \\
IL-18 & Urine & Intermediate & Absent \\
KIM 1 & Urine & Not tested & Not tested \\
\hline
\end{tabular}

cirrhotic patients with renal impairment, and this is clearly reflected by its inclusion in the MELD score.

Serum creatinine should be monitored daily in patients with acute impairment of renal function; small increases of $0.3-0.5 \mathrm{mg} / \mathrm{dL}$ may indicate marked reductions in GFR.

Serum sodium and potassium concentrations should be monitored frequently. Hyponatremia due to fluid overload and diuretics, and hyperkalemia due to potassium-sparing diuretics are frequently seen.

Urine analysis should be done to rule out renal parenchymal disease preferably with 24-hour urine samples. Renal ultrasonography should be performed to rule out intrinsic kidney disease or postrenal causes of AKI. Renal biopsy is recommended when there is a suspicion of renal parenchymal disease. Severe coagulopathy can pose a hazard and is a contraindication for renal biopsy.

\section{Evaluation of Liver Function}

A detailed look at the previous hospital records and laboratory parameters in addition to the clinical history can guide us with the status of liver dysfunction. Full set of laboratory investigations including complete hemogram and standard liver function tests including prothrombin time must be done. An ultrasound Doppler to look for patency of portal vein should be performed to rule out acute portal vein thrombosis as a cause for acute decompensation in liver function precipitating AKI. UGI endoscopy is helpful for diagnosing and treating gastroesophageal varices if there is a drop in hemoglobin and hemodynamic instability.

\section{Assessment of Bacterial Infection}

Bacterial infection should be ruled out in all patients with acute renal failure or worsening of renal function. Hypersplenism present in these patients masks the classical leukocytosis response to infection. ${ }^{38}$ A diagnostic tap should be done to rule out SBP. Chest radiography, and blood and urine cultures should be performed to rule out infection.

\section{Initial Measures}

Stop all diuretics and offending agents. Broad-spectrum antibiotic prophylaxis has to be instituted as per the hospital antibiogram.

The assessment of intravascular volume status and predicting fluid responsiveness in cirrhotic patients with ascites is very challenging. ${ }^{39}$ The ideal tool which has been validated to predict fluid responsiveness in these patients is with cardiac output measured by a pulmonary artery catheter which is difficult and thought to be invasive in most instances. The use of CVP as a predictor of fluid responsiveness has been challenged in many studies. IVC collapsibility index measured with bedside echocardiogram and pulse pressure variation/stroke volume variation measured by pulsed contour cardiac output monitors have become popular in liver intensive care units.

\section{UGI Bleeding}

Aggressive rapid resuscitation of patients to restore hemodynamic stability and near-normal hematocrit followed by endoscopic interventions reduces mortality in patients presenting with massive UGI bleeding. ${ }^{40}$

\section{SBP}

Renal impairment has been shown as the most important predictor of hospital mortality in cirrhotic patients with SBP. ${ }^{41-43}$ It has been 
shown in a randomized controlled study that treatment of SBP with appropriate antibiotics and albumin reduces the incidence of HRS from 30 to $10 \%$ and the mortality from 29 to $10 \%$ compared to treatment with antibiotics alone. Treatment with albumin has been particularly effective when bilirubin is more than $4 \mathrm{mg} / \mathrm{dL}$ and creatinine is more than $1 \mathrm{mg} / \mathrm{dL}$. It is not clear if albumin would be effective when creatinine and bilirubin values are beyond these limits. Until further evidence emerges, it has been recommended to use albumin in all patients who develop SBP. ${ }^{41}$

\section{Volume Expansion and Vasoconstrictors}

Volume expansion is the initial treatment in these patients. Vasoconstrictors are the mainstay of treatment in HRS-1 because of the altered circulatory dynamics. ${ }^{44,45}$ Well-designed randomized controlled trials have demonstrated that the combination of albumin with vasoconstrictors is superior to monotherapy in terms of HRS reversal, improvement of renal function, mean arterial blood pressure, and improvements in urine output. ${ }^{46,47}$ Because of its hyperoncotic properties, the use of 20 or $25 \%$ albumin causes redistribution of fluid into the circulation and accelerates volume expansion by $210-260 \%$ of the administered volume, can also decrease plasma renin activity, and can improve renal perfusion pressure. ${ }^{27,48,49} \mathrm{~A}$ dose-response relationship is observed between volume of albumin infused and survival in these patients, and a $49 \%$ reversal in HRS is observed in patients treated with combined albumin and vasoconstrictors. ${ }^{50}$ The reversal of HRS seen with vasoconstrictors is primarily due to their effect on increasing mean arterial pressure. $^{51}$

Terlipressin is proposed as the first choice of vasoconstrictor in HRS because of its selective action on V1 receptors. ${ }^{46,47,52-54}$ The regimen usually recommended is $0.5-1 \mathrm{mg}$ bolus followed by the same dose every 4-6 hours, and it can be increased to $2 \mathrm{mg} \mathrm{4-6}$ hourly if there is no proper response within 3 days. Continuous infusion of terlipressin at a dose of 2 gm over 24 hours was better tolerated than intermittent boluses, and the effective daily dose requirement was also less. ${ }^{55}$ The commonly reported adverse effects are diarrhea, abdominal cramps, arrhythmias, and ischemic complications; some of these can be serious necessitating discontinuation of the drug in $7 \%$ of cases. ${ }^{56}$ Therefore, terlipressin should be avoided or used cautiously in patients with ischemic heart disease, cardiomyopathies, peripheral vascular disease, asthma and chronic obstructive pulmonary disease, and in patients older than 70 years of age.

Norepinephrine in combination with albumin has been shown to be effective in reversal of Type I HRS. ${ }^{57}$ In comparison with terlipressin, norepinephrine has similar efficacy levels in reversal of HRS and a comparable safety profile. ${ }^{58-61}$

The combination of albumin, midodrine, and octreotide has shown to decrease mortality in patients with HRS. ${ }^{62}$ Studies have reported a reduction in serum creatinine levels but failed to show a complete reversal of HRS. ${ }^{63,64}$ The response rate was significantly better with terlipressin. ${ }^{65}$

\section{Renal Replacement Therapy (RRT) in Cirrhotics}

Patients with HRS who do not respond to medical management will eventually require a liver transplantation. RRT should be offered in the interim to support kidney function. Posttransplant survival at 1 and 3 years is significantly lower in patients with HRS. ${ }^{66}$ The majority of HRS-1 patients experience an improvement in renal function posttransplant. ${ }^{67}$ The only factor consistently associated with the nonresolution of HRS-1 after transplantation was the duration on dialysis before transplantation; the risk increases by $6 \%$ for each day on dialysis. Therefore, patients with HRS requiring dialysis for more than 4 weeks' duration should be considered for combined liver kidney transplantation. ${ }^{68}$

\section{Indications for RRT in Cirrhotics}

The indications for RRT which have traditionally been described for patients with chronic kidney disease are not the same in the setting of AKI/HRS in cirrhotics. The main goals of RRT in this population are to maintain fluid, electrolyte, solute, and acid-base homeostasis; avoid further injury to kidney; and aid in the delivery of drugs and nutrition. ${ }^{17,69}$ Therefore, the indications for RRT in AKI can be broadly grouped into two:

1. For classical indications for renal replacement therapy Emergent therapy in life-threatening indications: hyperkalemia, metabolic acidosis, uremic complications, and volume overload. ${ }^{19}$

2. For renal support

- Volume control-To decrease morbidity associated with fluid overload. $^{70-72}$

- Nutritional supplements and drug delivery can be enhanced when the concern of fluid restriction is removed-this can help in faster recovery. ${ }^{73}$

- Permissive hypercapnia in acute lung injury (ALI) can be managed with RRT without inducing fluid overload and hypernatremia. ${ }^{74}$

- Solute modulation-changes in solute burden as in tumor lysis syndrome, hyperammonemia in acute liver failure, acute on chronic liver failure and metabolic liver diseases, cytokine manipulation in sepsis and SIRS. ${ }^{75}$ The vasoactive inflammatory mediators in sepsis and liver failure are similar and so are the hemodynamic presentation in the two conditions. Continuous renal replacement therapy (CRRT) can thus downregulate the inflammatory response by absorption and removal of cytokines such as TNF- and IL-6, which have been implicated in the development of AKI and HRS as well as the exacerbation of hepatic injury and other toxins in sepsis. ${ }^{75-77}$

\section{Modalities of RRT}

The various modalities of RRT available are:

- Intermittent hemodialysis (IHD)

- Continuous renal replacement therapy (CRRT)

o Continuous venovenous hemofiltration (CVVH)

o Continuous venovenous hemodialysis (CVVHD)

o Continuous venovenous hemodiafiltration (CVVHF)

- Slow continuous ultrafiltration (SCUF)

- Sustained low-efficiency dialysis (SLED)

- Peritoneal dialysis (PD).

Table 3 describes modalities frequently used in cirrhotics with renal dysfunction with their pros and cons.

The two studies comparing PD and CRRT in AKI showed conflicting results. ${ }^{78,79}$ Better hemodynamic stability, lesser bleeding risks, ease of initiation, and nonrequirement for invasive vascular access have been proposed as advantages of PD in patients with cirrhosis. Major problems put forth are the huge protein losses, higher risks of peritonitis, and the potential to cause respiratory compromise with the diaphragmatic splinting that occurs due to raised intra-abdominal pressure. ${ }^{80} \mathrm{PD}$ has not found much favor among intensivists in the AKI setting. 
Table 3: Pros and cons of RRT modalities in cirrhosis

\begin{tabular}{|c|c|c|}
\hline Modality & Pros & Cons \\
\hline IHD & $\begin{array}{l}\text { Rapid clearance of toxins and solutes } \\
\text { Reduced requirement of } \\
\text { anticoagulation } \\
\text { Lower cost }\end{array}$ & $\begin{array}{l}\text { Hypotension } \\
\text { Dialysis } \\
\text { dysequilibrium }\end{array}$ \\
\hline CRRT & $\begin{array}{l}\text { Continuous removal of toxins and } \\
\text { well-controlled fluid and electrolyte } \\
\text { balance } \\
\text { Maintains hemodynamics and } \\
\text { intracranial pressure }\end{array}$ & $\begin{array}{l}\text { Requirement for } \\
\text { anticoagulation } \\
\text { Expensive } \\
\text { Risk of } \\
\text { hypothermia }\end{array}$ \\
\hline SLED & $\begin{array}{l}\text { Slower removal of fluid and solutes } \\
\text { Maintains hemodynamics } \\
\text { Reduced exposure to anticoagulants }\end{array}$ & $\begin{array}{l}\text { Slower clearance } \\
\text { of toxins }\end{array}$ \\
\hline
\end{tabular}

CRRT is favored over IHD in patients with cirrhosis because it is well tolerated with better cardiovascular stability, gradual correction of hyponatremia, and less fluctuation in intracranial pressures. ${ }^{81-84}$ Hyponatremia is a common complication seen in cirrhotics and more so in patients with volume overload in AKI. CRRT aids a gradual correction of sodium levels, thus preventing dangerous neurological complications, whereas abrupt changes in sodium levels can happen with IHD. ${ }^{85,86}$

\section{SLED}

SLED offers hemodynamic stability in comparison with CRRT; there is less need for anticoagulation and comparable control of urea, creatinine, and electrolytes. ${ }^{87-90}$ SLED has emerged as a reasonable compromise by maintaining hemodynamic stability and being less expensive than CRRT.

\section{SCUF}

SCUF is being used widely in our center for control of volume overload in cirrhotic patients who are diuretic intolerant or resistant with no other manifestations of renal dysfunction. The available evidence for SCUF is for patients with congestive heart failure (CHF). In volume-overloaded patients, with rapidly decompensating $\mathrm{CHF}$, SCUF can achieve more fluid removal and good weight loss, and avoid rehospitalization without changes in serum creatinine and hematocrit. $^{91-93}$

\section{Timing of Initiation of RRT}

In a trial involving critically ill patients with severe AKI, no significant difference was noticed in the mortality rates between an early vs delayed RRT. A delayed strategy averted the need for RRT in an appreciable number of patients. ${ }^{94}$ But from our clinical experience, we understand that early initiation of RRT is better in cirrhotics to control volume and electrolyte status and remove dangerous metabolites like lactates to avoid further downhill course.

\section{Choice of Buffer Solutions for RRT}

The use of bicarbonate as a buffer in the dialysate or replacement fluid in CRRT offers better correction of acidosis, lower lactate levels, and improved hemodynamics rapidly in comparison with lactate-based buffers. Patients with cirrhosis have poor tolerance to lactate-based buffers because of impaired clearance, and this effect is more pronounced when they present with multiorgan dysfunction. ${ }^{95-97}$

\section{Dosing of RRT}

Two large multicenter trials have demonstrated no benefits in increasing CRRT doses in AKI above effluent flows of $20-25 \mathrm{~mL} /$ $\mathrm{kg} / \mathrm{hr}$. To achieve this delivered dose, prescription must be in the range of $25-30 \mathrm{~mL} / \mathrm{kg} / \mathrm{hr}$, and there must be minimum interruptions in CRRT. ${ }^{98,99}$

High-volume hemofiltration has been proven to be beneficial in sepsis and can possibly improve outcomes in acute liver failure. ${ }^{76,100}$

\section{Anticoagulation in CRRT Circuits}

Much of the proposed benefits of CRRT can be achieved only with uninterrupted sessions. CRRT circuits seem to have a short life despite abnormal coagulation testing in cirrhotic patients. ${ }^{101}$ Safe use of heparin in circuits has been demonstrated in cirrhotic patients without increased bleeding complications and transfusion requirements. ${ }^{102}$ Morabito et al. proposed regional anticoagulation with heparin and protamine as a safe and valid alternative in critically ill patients on CRRT with short filter life. ${ }^{103}$ Citrate anticoagulation can be a good choice to prolong circuit life in patients at high risk of bleeding, but citrate accumulation poses a major hazard in patients with severely impaired liver function. ${ }^{104-106}$ A recent prospective multicenter observational study evaluated the effect of regional citrate anticoagulation in CRRT in patients with liver failure and concluded that it can be safely used in patients with liver failure and gives excellent filter patency. ${ }^{107}$

\section{Conclusion}

Because of the complex alteration in circulatory dynamics, renal dysfunction is very frequent in patients with cirrhosis and poses high morbidity and mortality. A thorough understanding of the pathogenesis, early detection, and aggressive corrective measures for AKI can prevent further progression. A good knowledge of treatment modalities available for renal dysfunction in cirrhosis and timely interventions can significantly improve survival in this group of patients.

\section{OrCID}

Akila Rajakumar (i) http://orcid.org/0000-0002-3279-7881

\section{References}

1. D'Amico G, Garcia-Tsao G, Pagliaro L. Natural history and prognostic indicators of survival in cirrhosis: a systematic review of 118 studies. J Hepatol 2006;44(1):217-231. DOI: 10.1016/j.jhep.2005.10.013.

2. du Cheyron D, Bouchet B, Parienti JJ, Ramakers M, Charbonneau P. The attributable mortality of acute renal failure in critically ill patients with liver cirrhosis. Intensive Care Med 2005;31(12):1693-1699. DOI: 10.1007/s00134-005-2842-7.

3. Moreau R, Lebrec $D$. Acute renal failure in patients with cirrhosis: perspectives in the age of MELD. Hepatology 2003;37(2):233-243. DOI: 10.1053/jhep.2003.50084.

4. Gonwa TA, Klintmalm GB, Levy M, Jennings LS, Goldstein RM, Husberg BS. Impact of pretransplant renal function on survival after liver transplantation. Transplantation 1995;59(3):361-365.

5. Gonwa TA, McBride MA, Anderson K, Mai ML, Wadei H, Ahsan N. Continued influence of preoperative renal function on outcome of orthotopic liver transplant (OLTX) in the US: where will MELD lead us? Am J Transplant 2006;6(11):2651-2659. DOI: 10.1111/j.16006143.2006.01526.x.

6. Kamath PS, Kim WR, Advanced Liver Disease Study G. The model for end-stage liver disease (MELD). Hepatology 2007;45(3):797-805. DOI: 10.1002/hep.21563. 
7. Nair S, Verma S, Thuluvath PJ. Pretransplant renal function predicts survival in patients undergoing orthotopic liver transplantation. Hepatology 2002;35(5):1179-1185. DOI: 10.1053/jhep.2002.33160.

8. Gines P, Schrier RW. Renal failure in cirrhosis. N Engl J Med 2009:361:1279-1290. DOI: 10.1056/NEJMra0809139.

9. Arroyo V, Gines P, Gerbes AL, Dudley FJ, Gentilini P, Laffi G, et al. Definition and diagnostic criteria of refractory ascites and hepatorenal syndrome in cirrhosis. International Ascites Club. Hepatology 1996;23(1):164-176. DOI: 10.1002/hep.510230122.

10. Martin PY, Gines P, Schrier RW. Nitric oxide as a mediator of hemodynamic abnormalities and sodium and water retention in cirrhosis. N Engl J Med 1998;339(8):533-541. DOI: 10.1056/ NEJM199808203390807.

11. Schrier RW, Arroyo V, Bernardi M, Epstein M, Henriksen JH, Rodes J. Peripheral arterial vasodilation hypothesis: a proposal for the initiation of renal sodium and water retention in cirrhosis. Hepatology 1988;8(5):1151-1157. DOI: 10.1002/hep.1840080532.

12. Ros J, Claria J, To-Figueras J, Planaguma A, Cejudo-Martin P, Fernandez-Varo $G$, et al. Endogenous cannabinoids: a new system involved in the homeostasis of arterial pressure in experimental cirrhosis in the rat. Gastroenterology 2002;122(1):85-93. DOI: 10.1053/ gast.2002.30305.

13. Bosch J, Abraldes JG, Berzigotti A, Garcia-Pagan JC. Portal hypertension and gastrointestinal bleeding. Semin Liver Dis 2008;28(1):3-25. DOI: 10.1055/s-2008-1040318.

14. Gines A, Escorsell A, Gines P, Salo J, Jimenez W, Inglada L, et al. Incidence, predictive factors, and prognosis of the hepatorenal syndrome in cirrhosis with ascites. Gastroenterology 1993;105(1):229236. DOI: 10.1016/0016-5085(93)90031-7.

15. Munoz SJ. The hepatorenal syndrome. Med Clin North Am 2008;92(4):813-837, viii-ix. DOl: 10.1016/j.mcna.2008.03.007.

16. Pichler RH, Huskey J, Kowalewska J, Moiz A, Perkins J, Davis $\mathrm{CL}$, et al. Kidney biopsies may help predict renal function after liver transplantation. Transplantation 2016;100(10):2122-2128. DOI: 10.1097/TP.0000000000001334.

17. Jamieson NV, European PH1 Transplantation Study Group. A 20-year experience of combined liver/kidney transplantation for primary hyperoxaluria ( $\mathrm{PH} 1)$ : the European $\mathrm{PH} 1$ transplant registry experience 1984-2004. Am J Nephrol 2005;25:282-289. DOI: 10.1159/000086359.

18. Salerno F, Gerbes A, Gines P, Wong F, Arroyo V. Diagnosis, prevention and treatment of hepatorenal syndrome in cirrhosis. Gut 2007;56(9):1310-1318. DOI: 10.1136/gut.2006.107789.

19. Bellomo R, Kellum JA, Ronco C. Acute kidney injury. Lancet 2012;380(9843):756-766. DOI: 10.1016/S0140-6736(11)61454-2.

20. Mehta RL, Kellum JA, Shah SV, Molitoris BA, Ronco C, Warnock DG, et al. Acute Kidney Injury Network: report of an initiative to improve outcomes in acute kidney injury. Crit Care 2007;11:R31. DOI: 10.1186/cc5713.

21. Bories PN, Campillo B, Azaou L, Scherman E. Long-lasting NO overproduction in cirrhotic patients with spontaneous bacterial peritonitis. Hepatology 1997;25(6):1328-1333. DOI: 10.1002/ hep.510250604.

22. Hampel H, Bynum GD, Zamora E, El-Serag HB. Risk factors for the development of renal dysfunction in hospitalized patients with cirrhosis. Am J Gastroenterol 2001;96(7):2206-2210. DOI: 10.1111/j.1572-0241.2001.03958.x.

23. Terg R, Gadano A, Cartier M, Casciato P, Lucero R, Munoz A, et al. Serum creatinine and bilirubin predict renal failure and mortality in patients with spontaneous bacterial peritonitis: a retrospective study. Liver Int2009;29(3):415-419. DOI: 10.1111/j.14783231.2008.01877.x.

24. Biyik M, Ataseven H, Biyik Z, Asil M, Cifci S, Sayin S, et al. KDIGO (Kidney Disease: Improving Global Outcomes) criteria as a predictor of hospital mortality in cirrhotic patients. Turk J Gastroenterol 2016;27(2):173-179. DOI: 10.5152/tjg.2016.15467.

25. Fede G, D'Amico G, Arvaniti V, Tsochatzis E, Germani G, Georgiadis D, et al. Renal failure and cirrhosis: a systematic review of mortality and prognosis. J Hepatol 2012;56(4):810-818. DOI: 10.1016/j. jhep.2011.10.016.
26. Belcher JM, Garcia-Tsao G, Sanyal AJ, Bhogal H, Lim JK, Ansari N, et al. Association of AKI with mortality and complications in hospitalized patients with cirrhosis. Hepatology 2013;57(2):753-762. DOI: 10.1002/ hep. 25735 .

27. Ruiz-del-Arbol L, Monescillo A, Arocena C, Valer P, Gines P, Moreira V, et al. Circulatory function and hepatorenal syndrome in cirrhosis. Hepatology 2005;42(2):439-447. DOI: 10.1002/hep.20766.

28. Caregaro L, Menon F, Angeli P, Amodio P, Merkel C, Bortoluzzi A, et al. Limitations of serum creatinine level and creatinine clearance as filtration markers in cirrhosis. Arch Intern Med 1994;154(2):201-205. DOI: 10.1001/archinte.1994.00420020117013.

29. Francoz C, Glotz D, Moreau R, Durand F. The evaluation of renal function and disease in patients with cirrhosis. J Hepatol 2010;52(4):605-613. DOI: 10.1016/j.jhep.2009.11.025.

30. Gines P, Guevara M, Arroyo V, Rodes J. Hepatorenal syndrome. Lancet 2003;362(9398):1819-1827. DOI: 10.1016/S0140-6736(03)14903-3.

31. Mishra J, Dent C, Tarabishi R, Mitsnefes MM, Ma Q, Kelly C, et al. Neutrophil gelatinase-associated lipocalin (NGAL) as a biomarker for acute renal injury after cardiac surgery. Lancet 2005;365(9466):1231-1238. DOI: 10.1016/S0140-6736(05)74811-X.

32. Wagener G, Jan M, Kim M, Mori K, Barasch JM, Sladen RN, et al. Association between increases in urinary neutrophil gelatinaseassociated lipocalin and acute renal dysfunction after adult cardiac surgery. Anesthesiology 2006;105(3):485-491. DOI: 10.1097/00000542-200609000-00011.

33. Dharnidharka VR, Kwon C, Stevens G. Serum cystatin C is superior to serum creatinine as a marker of kidney function: a meta-analysis. Am J Kidney Dis 2002;40(2):221-226. DOI: 10.1053/ajkd.2002.34487.

34. Devarajan P. Biomarkers for the early detection of acute kidney injury. Curr Opin Pediatr 2011;23(2):194-200. DOI: 10.1097/ MOP.0b013e328343f4dd.

35. Omar M, Abdel-Razek W, Abo-Raia G, Assem M, El-Azab G. Evaluation of serum cystatin $C$ as a marker of early renal impairment in patients with liver cirrhosis. Int J Hepatol 2015;2015:309042. DOI: 10.1155/2015/309042.

36. Gerbes AL, Gulberg V, Bilzer M, Vogeser M. Evaluation of serum cystatin $C$ concentration as a marker of renal function in patients with cirrhosis of the liver. Gut 2002;50(1):106-110. DOI: 10.1136/gut.50.1.106.

37. Belcher JM, Sanyal AJ, Peixoto AJ, Perazella MA, Lim J, ThiessenPhilbrook $\mathrm{H}$, et al. Kidney biomarkers and differential diagnosis of patients with cirrhosis and acute kidney injury. Hepatology 2014;60(2):622-632. DOI: 10.1002/hep.26980.

38. Qamar AA, Grace ND. Abnormal hematological indices in cirrhosis. Can J Gastroenterol 2009;23(6):441-445. DOI: 10.1155/2009/591317.

39. Nadim MK, Durand F, Kellum JA, Levitsky J, O'Leary JG, Karvellas CJ, et al. Management of the critically ill patient with cirrhosis: a multidisciplinary perspective. J Hepatol 2016;64(3):717-735. DOI: 10.1016/j.jhep.2015.10.019.

40. Baradarian R, Ramdhaney S, Chapalamadugu R, Skoczylas L, Wang $\mathrm{K}$, et al. Early intensive resuscitation of patients with upper gastrointestinal bleeding decreases mortality. Am J Gastroenterol 2004;99(4):619-622. DOI: 10.1111/j.1572-0241.2004.04073.x.

41. Follo A, Llovet JM, Navasa M, Planas R, Forns X, Francitorra A, et al. Renal impairment after spontaneous bacterial peritonitis in cirrhosis: incidence, clinical course, predictive factors and prognosis. Hepatology 1994;20(6):1495-1501. DOI: 10.1002/hep.1840200619.

42. Sort P, Navasa M, Arroyo V, Aldeguer X, Planas R, Ruiz-del-Arbol L, et al. Effect of intravenous albumin on renal impairment and mortality in patients with cirrhosis and spontaneous bacterial peritonitis. N Engl J Med 1999;341(6):403-409. DOI: 10.1056/ NEJM199908053410603.

43. Cardenas A, Gines P. Management of patients with cirrhosis awaiting liver transplantation. Gut 2011;60(3):412-421. DOI: 10.1136/ gut.2009.179937.

44. StadlbauerV,WrightGA, Banaji M,Mukhopadhya A, MookerjeeRP,Moore $\mathrm{K}$, et al. Relationship between activation of the sympathetic nervous system and renal blood flow autoregulation in cirrhosis. Gastroenterology 2008;134(1):111-119. DOI: 10.1053/j.gastro.2007.10.055. 
45. Arroyo V, Terra C, Gines P. Advances in the pathogenesis and treatment of type-1 and type-2 hepatorenal syndrome. J Hepatol 2007;46(5):935-946. DOI: 10.1016/j.jhep.2007.02.001.

46. Neri S, Pulvirenti D, Malaguarnera M, Cosimo BM, Bertino G, Ignaccolo $\mathrm{L}$, et al. Terlipressin and albumin in patients with cirrhosis and type I hepatorenal syndrome. Dig Dis Sci 2008;53(3):830-835. DOI: 10.1007/ s10620-007-9919-9.

47. Martin-Llahi M, Pepin MN, Guevara M, Diaz F, Torre A, Monescillo A, et al. Terlipressin and albumin vs albumin in patients with cirrhosis and hepatorenal syndrome: a randomized study. Gastroenterology 2008;134(5):1352-1359. DOI: 10.1053/j.gastro.2008.02.024.

48. Brinch K, Moller S, Bendtsen F, Becker U, Henriksen JH. Plasma volume expansion by albumin in cirrhosis. Relation to blood volume distribution, arterial compliance and severity of disease. J Hepatol 2003;39(1):24-31. DOI: 10.1016/s0168-8278(03)00160-0.

49. Jacob M, Chappell D, Conzen P, Wilkes MM, Becker BF, Rehm M. Smallvolume resuscitation with hyperoncotic albumin: a systematic review of randomized clinical trials. Crit Care 2008;12(2):R34. DOI: 10.1186/ cc6812.

50. Salerno F, Navickis RJ, Wilkes MM. Albumin treatment regimen for type 1 hepatorenal syndrome: a dose-response meta-analysis. BMC Gastroenterol 2015;15:167. DOI: 10.1186/s12876-015-0389-9.

51. Velez JC, Nietert PJ. Therapeutic response to vasoconstrictors in hepatorenal syndrome parallels increase in mean arterial pressure: a pooled analysis of clinical trials. Am J Kidney Dis 2011;58(6):928-938. DOI: 10.1053/j.ajkd.2011.07.017.

52. Sanyal AJ, Boyer T, Garcia-Tsao G, Regenstein F, Rossaro L, Appenrodt B, et al. A randomized, prospective, double-blind, placebo-controlled trial of terlipressin for type 1 hepatorenal syndrome. Gastroenterology 2008;134(5):1360-1368. DOI: 10.1053/j.gastro.2008.02.014.

53. Gluud LL, Christensen K, Christensen E, Krag A. Systematic review of randomized trials on vasoconstrictor drugs for hepatorenal syndrome. Hepatology 2010;51(2):576-584. DOI: 10.1002/hep.23286.

54. Dobre M, Demirjian S, Sehgal AR, Navaneethan SD. Terlipressin in hepatorenal syndrome: a systematic review and meta-analysis. Int Urol Nephrol 2011;43(1):175-184. DOI: 10.1007/s11255-010-9725-8.

55. Cavallin M, Piano S, Romano A, Fasolato S, Frigo AC, Benetti G, et al. Terlipressin given by continuous intravenous infusion versus intravenous boluses in the treatment of hepatorenal syndrome: a randomized controlled study. Hepatology 2016;63(3):983-992. DOI: 10.1002/hep.28396.

56. Sagi SV, Mittal S, Kasturi KS, Sood GK. Terlipressin therapy for reversal of type 1 hepatorenal syndrome: a meta-analysis of randomized controlled trials. J Gastroenterol Hepatol 2010;25(5):880-885. DOI: 10.1111/j.1440-1746.2009.06132.x.

57. Duvoux C, Zanditenas D, Hezode C, Chauvat A, Monin JL, Roudot-Thoraval $\mathrm{F}$, et al. Effects of noradrenalin and albumin in patients with type I hepatorenal syndrome: a pilot study. Hepatology 2002;36(2):374-380. DOI: 10.1053/jhep.2002.34343.

58. Singh V, Ghosh S, Singh B, Kumar P, Sharma N, Bhalla A, et al. Noradrenaline vs. terlipressin in the treatment of hepatorenal syndrome: a randomized study. J Hepatol 2012;56(6):1293-1298. DOI: 10.1016/j.jhep.2012.01.012.

59. Alessandria C, Ottobrelli A, Debernardi-Venon W, Todros L, Cerenzia MT, Martini S, et al. Noradrenalin vs terlipressin in patients with hepatorenal syndrome: a prospective, randomized, unblinded, pilot study. J Hepatol 2007;47(4):499-505. DOI: 10.1016/j. jhep.2007.04.010.

60. Sharma P, Kumar A, Shrama BC, Sarin SK. An open label, pilot, randomized controlled trial of noradrenaline versus terlipressin in the treatment of type 1 hepatorenal syndrome and predictors of response. Am J Gastroenterol 2008;103(7):1689-1697. DOI: 10.1111/j.1572-0241.2008.01828.x.

61. Nassar Junior AP, Farias AQ, D' Albuquerque LA, Carrilho FJ, Malbouisson LM. Terlipressin versus norepinephrine in the treatment of hepatorenal syndrome: a systematic review and meta-analysis. PLoS One 2014;9(9):e107466. DOI: 10.1371/journal. pone. 0107466 .
62. Salerno F, Cazzaniga M, Merli M, Spinzi G, Saibeni S, Salmi A et al. Diagnosis, treatment and survival of patients with hepatorenal syndrome: a survey on daily medical practice. J Hepatol 2011;55(6):1241-1248. DOI: 10.1016/j.jhep.2011.03.012.

63. Karwa R, Woodis CB. Midodrine and octreotide in treatment of cirrhosis-related hemodynamic complications. Ann Pharmacother 2009;43(4):692-699. DOI: 10.1345/aph.1L373.

64. Tavakkoli H, Yazdanpanah K, Mansourian M. Noradrenalin versus the combination of midodrine and octreotide in patients with hepatorenal syndrome: randomized clinical trial. Int J Prev Med 2012;3(11):764-769.

65. Cavallin M, Kamath PS, Merli M, Fasolato S, Toniutto P, Salerno F, et al. Terlipressin plus albumin versus midodrine and octreotide plus albumin in the treatment of hepatorenal syndrome: a randomized trial. Hepatology 2015;62(2):567-574. DOI: 10.1002/hep.27709.

66. Lee JP, Kwon HY, Park JI, Yi NJ, Suh KS, Lee HW, et al. Clinical outcomes of patients with hepatorenal syndrome after living donor liver transplantation. Liver Transpl 2012;18(10):1237-1244. DOI: 10.1002/ It.23493.

67. Xu X, Ling Q, Zhang M, Gao F, He Z, You J, et al. Outcome of patients with hepatorenal syndrome type 1 after liver transplantation: Hangzhou experience. Transplantation 2009;87(10):1514-1519. DOI: 10.1097/TP.0b013e3181a4430b.

68. Nadim MK, Sung RS, Davis CL, Andreoni KA, Biggins SW, Danovitch GM, et al. Simultaneous liver-kidney transplantation summit: current state and future directions. Am J Transplant 2012;12(11):2901-2908. DOI: 10.1111/j.1600-6143.2012.04190.x.

69. Kidney Disease: Improving Global Outcomes (KDIGO) Acute Kidney Injury Work Group. KDIGO Clinical Practice Guideline for Acute Kidney Injury-Section 5: Dialysis Interventions for Treatment of AKI. Kidney Int Suppl 2012;2(1):89-115. DOI: 10.1038/kisup.2011.35.

70. Payen D, de Pont AC, Sakr Y, Spies C, Reinhart K, Vincent JL. A positive fluid balance is associated with a worse outcome in patients with acute renal failure. Crit Care 2008;12(3):R74. DOI: $10.1186 /$ cc6916.

71. Costanzo MR, Guglin ME, Saltzberg MT, Jessup ML, Bart BA, Teerlink JR, et al. Ultrafiltration versus intravenous diuretics for patients hospitalized for acute decompensated heart failure. J Am Coll Cardiol 2007;49(6):675-683. DOI: 10.1016/j.jacc.2006.07.073.

72. Bouchard J, Soroko SB, Chertow GM, Himmelfarb J, Ikizler TA, Paganini EP, et al. Fluid accumulation, survival and recovery of kidney function in critically ill patients with acute kidney injury. Kidney Int 2009;76(4):422-427. DOI: 10.1038/ki.2009.159.

73. Bouffard Y, Viale JP, Annat G, Delafosse B, Guillaume C, Motin J. Energy expenditure in the acute renal failure patient mechanically ventilated. Intensive Care Med 1987;13(6):401-404. DOI: 10.1007/BF00257684.

74. Bellomo R, Ronco C. Continuous haemofiltration in the intensive care unit. Crit Care 2000;4(6):339-345. DOI: 10.1186/cc718

75. Dellinger RP, Levy MM, Carlet JM, Bion J, Parker MM, Jaeschke R, et al. Surviving Sepsis Campaign: international guidelines for management of severe sepsis and septic shock: 2008. Intensive Care Med 2008;34(1):17-60. DOI: 10.1007/s00134-007-0934-2.

76. Servillo G, Vargas M, Pastore A, Procino A, lannuzzi M, Capuano A, et al. Immunomodulatory effect of continuous venovenous hemofiltration during sepsis: preliminary data. Biomed Res Int 2013:2013:108951. DOI: 10.1155/2013/108951.

77. Ronco C, Bonello M, Bordoni V, Ricci Z, D'Intini V, Bellomo R, et al. Extracorporeal therapies in non-renal disease: treatment of sepsis and the peak concentration hypothesis. Blood Purif 2004;22(1):164-174. DOI: 10.1159/000074937.

78. Phu NH, Hien TT, Mai NT, Chau TT, Chuong LV, Loc PP, et al. Hemofiltration and peritoneal dialysis in infection-associated acute renal failure in Vietnam. N Engl J Med 2002;347(12):895-902. DOI: 10.1056/NEJMoa020074.

79. Gabriel DP, Caramori JT, Martim LC, Barretti P, Balbi AL. High volume peritoneal dialysis vs daily hemodialysis: a randomized, controlled trial in patients with acute kidney injury. Kidney Int Suppl 2008;(108):S87-S93. DOI: 10.1038/sj.ki.5002608. 
80. Guest S. Peritoneal dialysis in patients with cirrhosis and ascites. Adv Perit Dial 2010;26:82-87.

81. Davenport A. Renal replacement therapy in the patient with acute brain injury. Am J Kidney Dis 2001;37(3):457-466.

82. Davenport A, Bouman C, Kirpalani A, Skippen P, Tolwani A, Mehta RL, et al. Delivery of renal replacement therapy in acute kidney injury: what are the key issues? Clin J Am Soc Nephrol 2008;3(3):869-875. DOI: $10.2215 / C J N .04821107$.

83. Davenport A, Will EJ, Davison AM. Effect of renal replacement therapy on patients with combined acute renal and fulminant hepatic failure. Kidney Int Suppl 1993;41:S245-S251.

84. Bagshaw SM, Berthiaume LR, Delaney A, Bellomo R. Continuous versus intermittent renal replacement therapy for critically ill patients with acute kidney injury: a meta-analysis. Crit Care Med 2008;36(2):610-617. DOI: 10.1097/01.CCM.0B013E3181611F552.

85. AdrogueHJ,Madias NE. Hyponatremia. NEnglJMed 2000;342(21):15811589. DOI: $10.1056 /$ NEJM200005253422107.

86. Sterns RH, Cappuccio JD, Silver SM, Cohen EP. Neurologic sequelae after treatment of severe hyponatremia: a multicenter perspective. J Am Soc Nephrol 1994;4(8):1522-1530.

87. Baldwin I, Bellomo R, Naka T, Koch B, Fealy N. A pilot randomized controlled comparison of extended daily dialysis with filtration and continuous veno-venous hemofiltration: fluid removal and hemodynamics. Int J Artif Organs 2007;30(12):1083-1089. DOI: $10.1177 / 039139880703001208$.

88. Baldwin I, Naka T, Koch B, Fealy N, Bellomo R. A pilot randomised controlled comparison of continuous veno-venous haemofiltration and extended daily dialysis with filtration: effect on small solutes and acid-base balance. Intensive Care Med 2007;33(5):830-835. DOI: 10.1007/s00134-007-0596-0.

89. Marshall MR, Creamer JM, Foster M, Ma TM, Mann SL, Fiaccadori E, et al. Mortality rate comparison after switching from continuous to prolonged intermittent renal replacement for acute kidney injury in three intensive care units from different countries. Nephrol Dial Transplant 2011;26(7):2169-2175. DOI: 10.1093/ndt/gfq694.

90. Fieghen HE, Friedrich JO, Burns KE, Nisenbaum R, Adhikari NK, Hladunewich MA, et al. The hemodynamic tolerability and feasibility of sustained low efficiency dialysis in the management of critically ill patients with acute kidney injury. BMC Nephrol 2010;11:32. DOI: 10.1186/1471-2369-11-32.

91. Costanzo MR, Saltzberg MT, Jessup M, Teerlink JR, Sobotka PA, Ultrafiltration Versus Intravenous Diuretics for Patients Hospitalized for Acute Decompensated Heart Failure I. Ultrafiltration is associated with fewer rehospitalizations than continuous diuretic infusion in patients with decompensated heart failure: results from UNLOAD. J Card Fail 2010;16(4):277-284. DOI: 10.1016/j.cardfail.2009.12.009.

92. Wen $\mathrm{H}$, Zhang $\mathrm{Y}$, Zhu J, Lan $\mathrm{Y}$, Yang $\mathrm{H}$. Ultrafiltration versus intravenous diuretic therapy to treat acute heart failure: a systematic review. Am J Cardiovasc Drugs 2013;13(5):365-373. DOI: 10.1007/ s40256-013-0034-3.

93. Bart BA, Boyle A, Bank AJ, Anand I, Olivari MT, Kraemer M, et al. Ultrafiltration versus usual care for hospitalized patients with heart failure: the Relief for Acutely Fluid-Overloaded Patients With Decompensated Congestive Heart Failure (RAPID-CHF) trial. J Am Coll Cardiol 2005;46(11):2043-2046. DOI: 10.1016/j.jacc.2005.05.098.
94. Gaudry S, Hajage D, Schortgen F, Martin-Lefevre L, Pons B, Boulet E, et al. Initiation strategies for renal-replacement therapy in the intensive care unit. N Engl J Med 2016;375(2):122-133. DOI:10.1056/ NEJMoa1603017.

95. McLean AG, Davenport A, Cox D, Sweny P. Effects of lactatebuffered and lactate-free dialysate in CAVHD patients with and without liver dysfunction. Kidney Int 2000;58(4):1765-1772. DOI: 10.1046/j.1523-1755.2000.00338.x.

96. Thomas AN, Guy JM, Kishen R, Geraghty IF, Bowles BJ, Vadgama P. Comparison of lactate and bicarbonate buffered haemofiltration fluids: use in critically ill patients. Nephrol Dial Transplant 1997;12(6):1212-1217. DOI: 10.1093/ndt/12.6.1212.

97. Tan HK, Uchino S, Bellomo R. The acid-base effects of continuous hemofiltration with lactate or bicarbonate buffered replacement fluids. Int J Artif Organs 2003;26(6):477-483. DOI: $10.1177 / 039139880302600605$.

98. Bellomo R, Cass A, Cole L, Finfer S, Gallagher M, Lo S, et al. Intensity of continuous renal-replacement therapy in critically ill patients. N Engl J Med 2009;361(17):1627-1638. DOI: 10.1056/ NEJMoa0902413.

99. Palevsky PM, Zhang JH, O'Connor TZ, Chertow GM, Crowley ST, Choudhury D, et al. Intensity of renal support in critically ill patients with acute kidney injury. N Engl J Med 2008;359:7-20. DOI: 10.1056/ NEJMoa0802639.

100. Bikhchandani J, Metcalfe M, Illouz S, Puls F, Dennison A. Extracorporeal liver perfusion system for artificial liver support across a membrane. J Surg Res 2011;171(1):e139-147. DOI: 10.1016/j. jss.2011.07.014.

101. Chua HR, Baldwin I, Bailey M, Subramaniam A, Bellomo R. Circuit lifespan during continuous renal replacement therapy for combined liver and kidney failure. J Crit Care 2012;27(6):744.e7-744.e15. DOI: 10.1016/j.jcrc.2012.08.016.

102. Agarwal B, Shaw S, Shankar Hari M, Burroughs AK, Davenport A. Continuous renal replacement therapy (CRRT) in patients with liver disease: is circuit life different? J Hepatol 2009;51(3):504-509. DOI: 10.1016/j.jhep.2009.05.028.

103. Morabito S, Guzzo I, Solazzo A, Muzi L, Luciani R, Pierucci A. Continuous renal replacement therapies: anticoagulation in the critically ill at high risk of bleeding. J Nephrol 2003;16(4):566-571.

104. Kramer L, Bauer E, Joukhadar C, Strobl W, Gendo A, Madl C, et al. Citrate pharmacokinetics and metabolism in cirrhotic and noncirrhotic critically ill patients. Crit Care Med 2003;31(10):2450-2455. DOI: 10.1097/01.CCM.0000084871.76568.E6.

105. Apsner R, Schwarzenhofer M, Derfler K, Zauner C, Ratheiser K, Kranz A. Impairment of citrate metabolism in acute hepatic failure. Wien Klin Wochenschr 1997;109(4):123-127.

106. Durao MS, Monte JC, Batista MC, Oliveira M, lizuka IJ, Santos BF, et al. The use of regional citrate anticoagulation for continuous venovenous hemodiafiltration in acute kidney injury. Crit Care Med 2008;36(11):3024-3029. DOI: 10.1097/CCM.0b013e31818b9100.

107. Slowinski T, Morgera S, Joannidis M, Henneberg T, Stocker R, Helset E, et al. Safety and efficacy of regional citrate anticoagulation in continuous venovenous hemodialysis in the presence of liver failure: the Liver Citrate Anticoagulation Threshold (L-CAT) observational study. Crit Care 2015;19():349. DOI: 10.1186/s13054-015-1066-7. 